\title{
DIRASAH
}

Volume 2, Number 2, Agustus 2019

p-ISSN: 2615-0212 | e-ISSN: 2621-2838

https://ejournal.iaifa.ac.id/index.php/dirasah

\begin{tabular}{|l|c|c|}
\hline Accepted: & Revised: & Published: \\
Maret 2019 & Juli 2019 & Agustus 2019 \\
\hline
\end{tabular}

\section{Pengembangan Media Monopoli Berbasis Triprakoro Pada Pembelajaran Tematik di MI Al-Ittihad Jogoroto Jombang}

\author{
Rafika Dwi Ismayati \\ Universitas Hasyim Asy'ari Tebuireng Jombang, Indonesia \\ e-mail:rafikadwiismayati@gmail.com

\begin{abstract}
Ali Mahsun
Universitas Hasyim Asy'ari Tebuireng Jombang, Indonesia e-mail: alimahsun000@gmail.com
\end{abstract}

\begin{abstract}
Thematic learning is part of the 2013 curriculum which is being implemented as an educational system, which requires teachers to be creative and innovative in implementing the learning proccess, so that media development in needed to attract students' enthusiasm for learning in enhancing the overall understanding of thematic material. Based on this, in this study, researches developed Monochromatic Media (Triprakoro thematic material-based Monopoly) class IV Madrasah Ibtidaiyyah. The research method used is $R \& D$ (Research \& Development) Borg and Gall development model by adapting 8 steps namely potential and problems, data collection, product design, design validation, design revision and trial use. Based on the development of monochromatic products, the validation results obtained are: validation of material experts got a score of $92 \%$ with very decent criteria, validation of learning design experts got a score of $92 \%$ with decent criteria, and validation of learning experts got a score of 92\% with very decent criteria. Trial of product attractiveness based on assesment and student responses scored $88,7 \%$ with very interesting criteria. Thus it can be concluded that monochromatic media is effectively used in learning in madrasas.
\end{abstract}

Keywords: Learning Media, Triprakoro, Thematic Learning 


\section{Pendahuluan}

Pendidikan adalah kebutuhan setiap manusia. Setiap individu memerlukan pendidikan sebagai upaya memperkaya pengetahuan dan membentuk kepribadian serta pengembangan keterampilan baik secara rohani maupun jasmani. Kegiatan belajar akan memberikan pengetahuan serta pengalaman dalam mengubah perilaku dan kemampuan dalam berfikir kritis atau pengembangan potensi yang dimilikinya sesuai dengan Undang Undang No. 20 Tahun 2003 tntang tujuan pendidikan nasional.

Selaras dengan tujuan pendidikan nasional, saat ini kurikulum 2013 digunakan sebagai sistem pendidikan nasional yang lebih ditekankan pada penanaman karakter. Dalam implementsi kurikulum 2013 melibatkan banyak komponen diantaranya kurikulum, rencana pembelajaran, proses pembelajaran, mekanisme penilaian, kualitas hubungan, pengelolaan pembelajaran, pemberdayaan sarana prasarana, pengelolaan madrasah, pelaksanaan pengembangan diri peserta didik, pembiayaan serta etos kerja seluruh warga dan lingkungan sekolah/madrasah. ${ }^{1}$

Menurut teori Gestalt dalam Pengembangan dan Implementasi Kurikulum 2013 seseorang dikatakan berhasil dalam proses belajar jika mendapat insight (pemahaman antar bagian). Pendekatan yang cocok untuk mendukung proses kegiatan belajar secara utuh siswa dalam memahami antar bagian bagian materi yaitu pembelajaran tematik. Sesuai dengan Peraturan Menteri Pendidikan dan Kebudayaan No. 67 Tahun 2013 bahwa Kurikulum 2013 untuk sekolah dasar kelas 1- 6 didesain menggunakan pembelajaran tematik terpadu. Pembelajaran tematik yaitu suatu sistem pembelajaran yang memberikan ruang bagi peserta didik untuk aktif menggali dan menemukan konsep serta prinsip-prinsip keilmuan secara holistik, bermakna dan autentik baik secara individu maupun kelompok. $^{2}$

Dalam proses pembelajaran ada prinsip-prinsip belajar yang harus ketahui salah satunya yakni prinsip belajar sambil bermain. ${ }^{3}$ Belajar sambil bermain dirasa cukup efektif mengingat masa SD/MI adalah masa peralihan dari TK

\footnotetext{
${ }^{1}$ Mulyasa, Pengembangan dan Implementasi Kurikulum 2013 (Bandung: PT Remaja Rosda Karya, 2015), 7.

2 Rusman, Model-Model Pembelajaran Mengembangkan Profesionalisme Guru (Jakarta: Raja Grafindo Persada, 2014), 254.

3 Ahmad Susanto, Teori belajar dan Pembelajaran di Sekolah Dasar (Jakarta: Prenamedia Group. 2016), 87-88.
}

Dirasah, Vol. 2, No. 2, Agustus 2019 
yang prinsipnya bermain sambil belajar kemudian beralih ke SD/MI dengan prinsip belajar sambil bermain.

Kepala subdirektorat peningkatan kompetensi dan kualifikasi direktorat pembinaan guru pendidikan dasar kemendikbud Elvira dalam sosialisasi di tasikmalaya meyatakan bahwa guru perlu meningkatkan kompetensi secara terus menerus seiring perkembangan zaman (Kemendikbud.go.id). Anggota DPR RI Ferdiansyah juga mengungkapkan bahwa guru adalah kurikulum yang sebenarnya, dimana peran guru sangatlah penting, terutama dijenjang pendidikan dasar. Guru harus mampu menciptakan susasana belajar yang menyenangkan, kreatif, dinamis dan dialogis. Dalam rangka mencapai tujuan pendidikan yang utuh maka pendidik diharuskan menggunakan media pembelajaran sebagai alat untuk siswa lebih mudah dalam memahami proses pembelajaran.

Media pembelajaran adalah segala bentuk alat komunikasi yang digunakan untuk menyampaikan informasi dari sumber ke peserta didik sehingga proses belajar menjadi efisien dan efektif ${ }^{4}$ Media yang tepat akan berimbas dengan tercapainya tujuan pembelajaran.

Anas Sudjino menyatakan bahwa terdapat tujuh alasan guru enggan menggunakan media pembelajaran, pertama menggunakan media itu repot, kedua media itu canggih dan mahal, ketiga guru tidak terampil menggunakan media, keempat media itu hiburan sedangkan belajar itu serius, kelima tidak tersedia di sekolah, keenam kebiasaan menikmati ceramah/bicara, ketujuh kurangnya penghargaan dari atasan..$^{5}$ Ketujuh alasan inilah yang mendorong penggunaan media pembelajaran di sekolah tidak variatif. Hal tersebut cenderung membuat peserta didik merasa jenuh dalam melakasanakan proses pembelajaran, merasa pembelajaran tidak menarik. Terlebih di tingkat sekolah dasar masih membutuhkan penjelasan yang konkret dan bisa dirasakan langsung agar pembelajaran yang dilakukan tidak abstrak atau berandai-andai. Sesuai dengan teori perkembangan Piaget, bahwa anak pada usia 7-11 tahun memasuki tahap Operasional Konkret.

Dengan adanya kesenjangan tersebut maka peneliti memiliki solusi yaitu dengan mengembangakan media monokromatik (monopoli berbasis triprkoro

\footnotetext{
${ }^{4}$ Nina Lamatenggo dan Hamzah, Teknologi Komunikasi \& Informasi Pembelajaran (Jakarta: PT. Bumi Aksara, 2011), 121.

${ }^{5}$ Anas Sudijino, Pengantar Evaluasi Pendidikan (Jakarta: PT. Raja Grafindo, 2009), 80.
} 
materi tematik) yaitu permainan monopoli yang dikembangakjan dengan model triprakoro sebagai penguat dalam penanaman karakter siswa yang diharapkan memberikan dampak positif dalam menanamakan nilai-nilai pada materi tematik. Zetti Finali dalam penelitiannya menyatakan bahwa hasil belajar siswa secara kognitif serta aktivitas atau sikap siswa saat pembelajaran sesuai dengan model triprakoro menunjukkan kevalidan berdasarkan kriteria yang telah ditentukan. ${ }^{6}$ Monokromatik diharapkan mampu digunakan sebagai alat belajar untuk mempermudah siswa dalam memahami materi tematik khususnya siswa kelas IV MI Al-Ittihad. Oleh karena itu dirumuskan dalam judul Pengembangan Media Monopoli Berbasis Triprakoro pada Pembelajaran Tematik kelas IV MI Al-Ittihad Jogoroto.

\section{Metode Penelitian}

Dalam penelitian ini peneliti menggunakan metode penelitian dan pengembangan $(\mathrm{R} \& \mathrm{D})$ dengan model pengembangan dari Borg and Gall dengan sepuluh tahapan. ${ }^{7}$ Pada penelitian dan pengembangan ini, tahapan prosedur hanya dilaksanakan sampai tahap kedelapan dengan pertimbangan bahwa pengembangan media ajar yang dilaksanakan hanya sebatas ujicoba produk. Tahapan kesembilan dan kesepuluh tidak dilaksanakan karena terbatasnya waktu penelitian sehingga penelitian tidak bisa dilakukan ke tahap selanjutnya.

Prosedur dalam penelitian ini meliputi menggali potensi dan masalah sebagai langkah awal penelitian, kemudian mengumpulkan data dan bahan untuk perencanaan produk untuk mengatasi potensi atau masalah dengan melakukan observasi, pengisian angket, wawancara dan dokumentasi ke sekolah, membuat desain produk yang akan dikembangkan, melaksanakan proses validasi desain produk pada para ahli, melakukan perbaikan desain produk berdasarkan saran dan masukan dari validator ahli, uji coba produk pada skala kecil untuk mengetahui kelayakan produk, revisi produk sebagai perbaikan, uji coba pemakaian dilakukan menggunakan desain true experimental dengan model posttest only control dalam skala besar, untuk menganalisis efektifitas produk digunakan statistic parametrik uji beda t-test.

${ }^{6}$ Zetti finali, "Pegembangan RPP Pkn Berbasis Model Triprakoro Dan Budaya Lokal (Using) Untuk Mengembangkan Nilai Komunikatif Pada Kelas IV Sekolah Dasar", Jurnal Pendidikan, vol. 5 (Universitas Negeri Malang: 2016), 213.

${ }^{7}$ Sugiyono. Metode Penelitian Pendidikan Pendekatan Kuantitatif, Kualitatif, dan R\&D. Cet. 25 (Bandung: Alfabeta, 2017), 297.

Dirasah, Vol. 2, No. 2, Agustus 2019 
Subjek penelitian ini adalah Siswa kelas IV di Madrasah Ibtidaiyah AlIttihad Jogoroto.

Instrument yang digunakan dalam pengumpulan data pada penelitian pengembangan ini adalah angket penilaian ahli materi, Angket penilaian ahli desain media pembelajaran, angket penilaian ahli pembelajaran, angket penilaian siswa uji coba lapangan, butir soal untuk post tes dan lembar observasi.

Jenis data yang digunakana adalah data kualitatif dan kuantitatif. Data kualitatif diperoleh dari tanggapan dan saran perbaikan dari hasil rivew validator dalam bentuk wawancara dan siswa. Sedangkan data kuantitatif didapatkan dari penilaian yang diberikan validator dalam bentuk skor serta observasi aktifitas siswa setelah menggunakan media monopoli berbasis triprakoro.

Teknik pengambilan data dilaksanakan dengan observasi, wawancara dan angket yang ditujukan kepada validator ahli berdasarkan pengembangan yang dilakukan dan uji coba siswa terhadap produk.

Analisis data yang digunakan dalam penelitian ini meliputi tiga teknik diantaranya: Analisis isi pembelajaran yaitu dengan merumuskan tujuan pembelajaran yang disesuaikan dengan Standar Kompetensi dan Kompetensi Dasar untuk menyusun isi dari media monopoli berbasis triprakoro yang sedang dikembangkan.

Analisis deskriptif merupakan pemaparan dari hasil pengembangan produk yang dilakukan oleh peneliti. ${ }^{8}$ Hasil dari analisis deskriptif ini digunakan untuk menemukan tingkat kelayakan, keefektifan dan kemenarikan produk penelitian. Data yang berbentuk simbol akan dianalisis dengan cara mendeskripsikan semua pendapat, saran, dan tanggapan dari validator, sedangkan data yang berbentuk angka akan dianalisis dengan cara persentase, berikut rumusnya ${ }^{9}$

$$
\mathrm{P}=\frac{\sum x}{\sum x i} \mathrm{X} 100 \%
$$

Keterangan:

$\mathrm{P} \quad=$ Presentase kelayakan

$\sum x=$ Jumlah total skor yang akan diperoleh dari validator

$\sum x i=$ Jumlah skor ideal

${ }^{8}$ Sugiyono. Metode Penelitian., 373.

9 Suharsimi Arikunto, Prosedur Penelitian Suatu Pendekatan Praktik (Jakarta: Rineka Cipta, 2013), 313. 
Analisis hasil eksperimen (Posttest) digunakan untuk menghitung nilai rata-rata posstest dari seluruh siswa.

\section{Hasil Penelitian}

Produk yang dihasilkan dari penelitian dan pengembangan ini merupakan media monopoli berbasis triprakoro dengan mengaitkan dengan pembelajaran tematik atau lebih singkat disebut Monokromatik.

Sebelum melaksanakan proses pengembangan monokromatik terlebih dahulu dilaksanakan penggalian potensi dan masalah dengan melaksanakan observasi di MI Al-Itthad Jogoroto pada tanggal 12 Desember 2018. Berdasarakan observasi dan wawancara yang dilakukan peneliti ibu sekaligus guru mata pelajaran tematik Uzlifatul Ula S.Pd guru kelas IV, ditemukan masalah bahwa beberapa siswa yang tidak mengikuti pembelajaran dengan baik karena kurang berminat dengan pembelajaran yang sedang berlangsung, selain itu pengembangan media ajar yang digunakan sekolah tersebut masih sangat umum hal tersebut mengakibatkan timbulnya kejenuhan bagi siswa untuk melaksanakan proses belajar sehingga menjadi salah satu faktor berkurangnya minat belajar siswa.

Berdasarkan data yang telah didapatkan maka peneliti memiliki solusi untuk masalah tersebut berupa monokromatik yaitu media monopoli berbasis triprakoro materi tematik. Dalam proses pengembangan monokromatik melalui beberapa langkah diantaranya: penyusunan konsep monopoli, desain gambar, penyusunan materi dan soal tematik sesuai dengan KI KD, dan pembuatan bagian-bagian pendukung monokromatik.

Monokromatik dikembangkan dengan memuat materi "Indahnya Keragaman di Indonesia" ini memiliki beberapa komponen antara lain yaitu:

Alas permainan dicetak menggunakan Banner dengan ukuran $90 \mathrm{cmx} 65 \mathrm{~cm}$. Pada bagian ini terdapat 40 petak secara keseluruhan dengan rincian: 20 petak rumah adat, 8 petak kegiatan ekonomi, 3 petak kesempatan, 3 petak dana umum, 2 petak gaya, 1 petak start, 1 petak Indonesia, 1 petak bebas parkir, 1 petak pajak bangunan,

Dirasah, Vol. 2, No. 2, Agustus 2019 


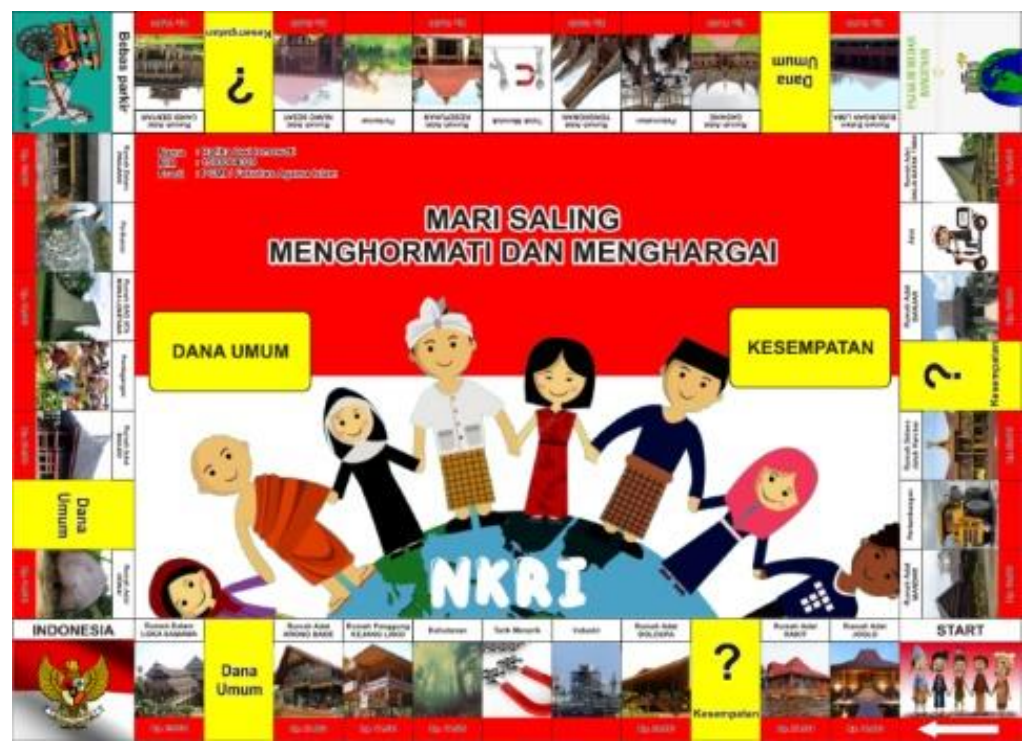

\section{Gambar 1. Alas Monopoli}

Kartu hak milik adalah kartu tanda milik rumah yang didapatkan setelah pemain membeli rumah dan melaksanakan transaksi dengan bank Monopoli sesuai dengan harga yang telah ditentukan. Kartu hak milik ini dicetak menggunakan kertas foto agar terlihat mengkilap dibagian cover. Kartu hak milik terdiri dari 4 sisi yaitu: Sisi utama adalah cover, sisi kedua adalah harga pembelian rumah, sisi ketiga adalah materi penjelasan dan sisi ke empat adalah lembar AKU BISA.

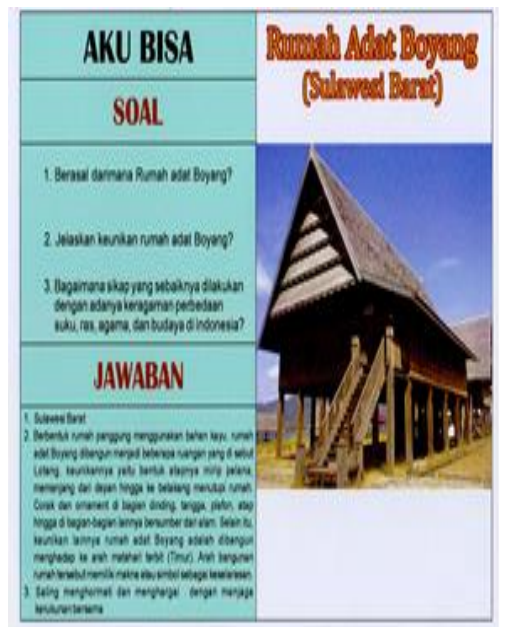

\begin{tabular}{|c|c|c|}
\hline \multicolumn{2}{|c|}{ HARGA SEWA } & \multirow{8}{*}{ 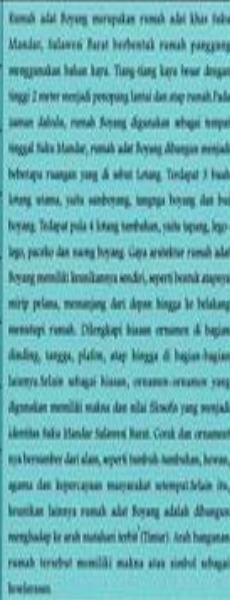 } \\
\hline Hanya Tanah & $R p, 18.000$ & \\
\hline 1. Rumah & Rp. 20.500 & \\
\hline 2. Rumah & Rp. 23.000 & \\
\hline 3. Rumah & $R p .25 .500$ & \\
\hline Hotel & $R p .30 .500$ & \\
\hline Harga Hipotik & Rp. 15.500 & \\
\hline \multicolumn{2}{|c|}{$\begin{array}{l}\text { Jika Tanah oi Hipotikan } \\
\text { Maka Kartu lni harus } \\
\text { O. Kembalikan Ke Bank } \\
\text { MONOPOLY INOONESIA }\end{array}$} & \\
\hline
\end{tabular}

Gambar 2. Kartu Hak Milik

Dirasah, Vol. 2, No. 2, Agustus 2019 
Kartu dana umum berisi tambahan materi tentang ragam agama dan suku yang ada di Indonesia. Kartu dana umum ini terdiri dari 10 kartu dengan ukuran $10 \mathrm{~cm}$ x $5 \mathrm{~cm}$ Dan dicetak menggunakan kertas buffalo tebal kemudian di laminating agar bertahan lama.

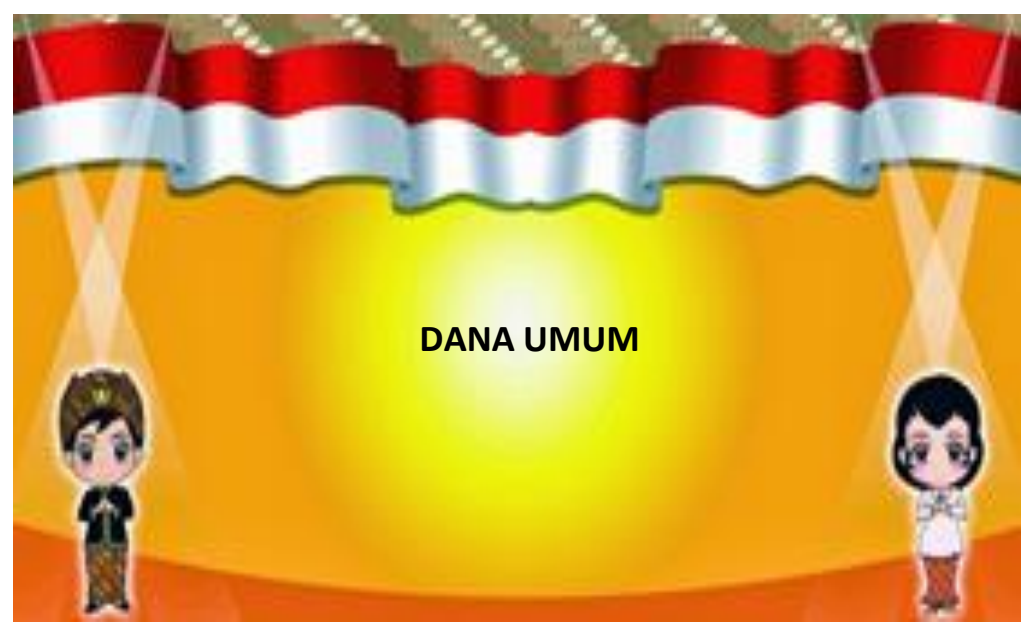

Gambar 3. Kartu Dana Umum

Kartu kesempatan merupakan kartu yang berisi tentang pertanyaanpertanyan seputar materi yang sedang dipelajari. Kartu kesempatan terdiri dari 10 lembar kartu, dicetak menggunakan kertas hvs tebal dengan ukuran $10 \mathrm{~cm} \mathrm{x}$ $5 \mathrm{~cm}$.

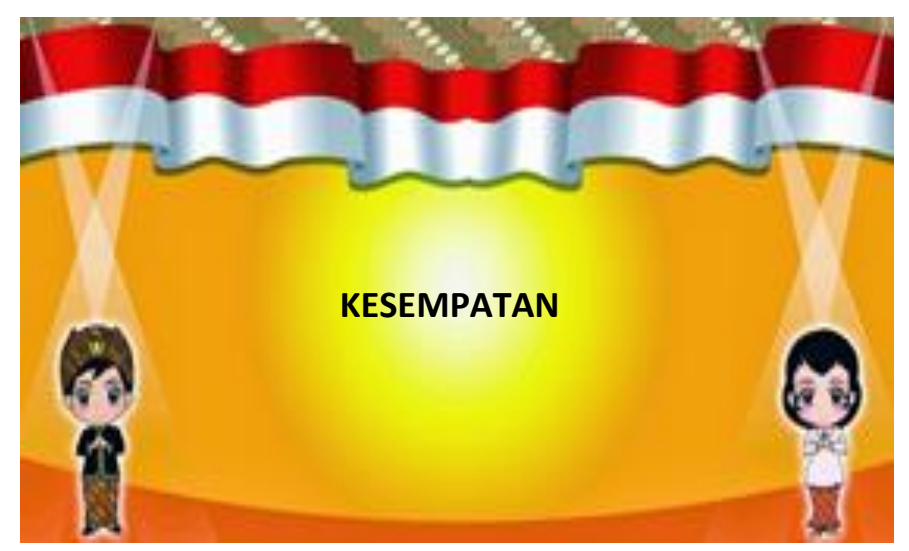

Gambar 4. Kartu Kesempatan 
Uang mainan monopoli didesain menggunakan gambar batik sebagai background utama kemudian gambar alat musik setempat di sisi depan kanan uang. Selain itu desain didalamnya juga memuat nama alat musik serta daerah asalnya. Uang mainan monopoli ini dicetak menggunakan kertas buffalo tebal.

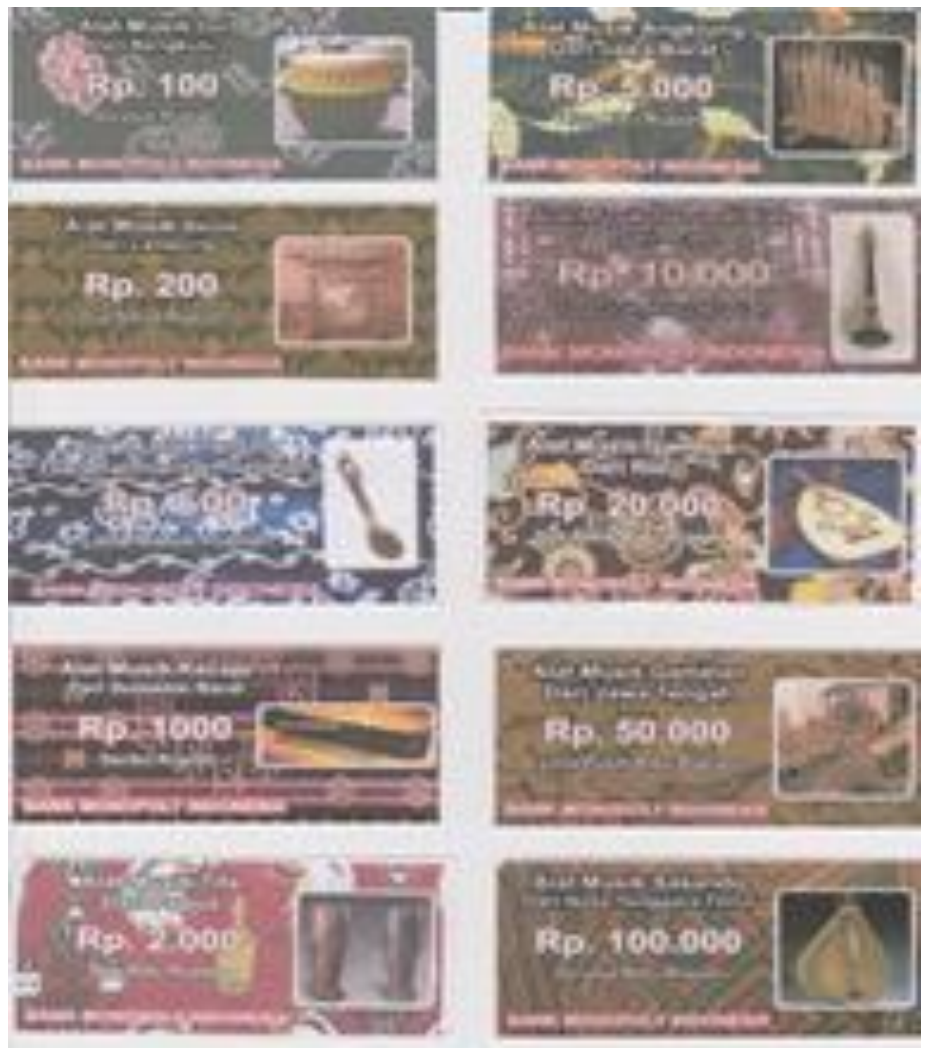

\section{Gambar 5. Uang Mainan}

Kartu petunjuk permainan terdiri dari 2 sub poin, yang pertama yaitu perlengkapan permainan dan yang kedua adalah peraturan permainan. Kartu petunjuk permainan ini dicetak menggunakan kertas foto agar nampak glossy. Dalam setiap box akan mendapatkan 1 kartu petunjuk permainan. 


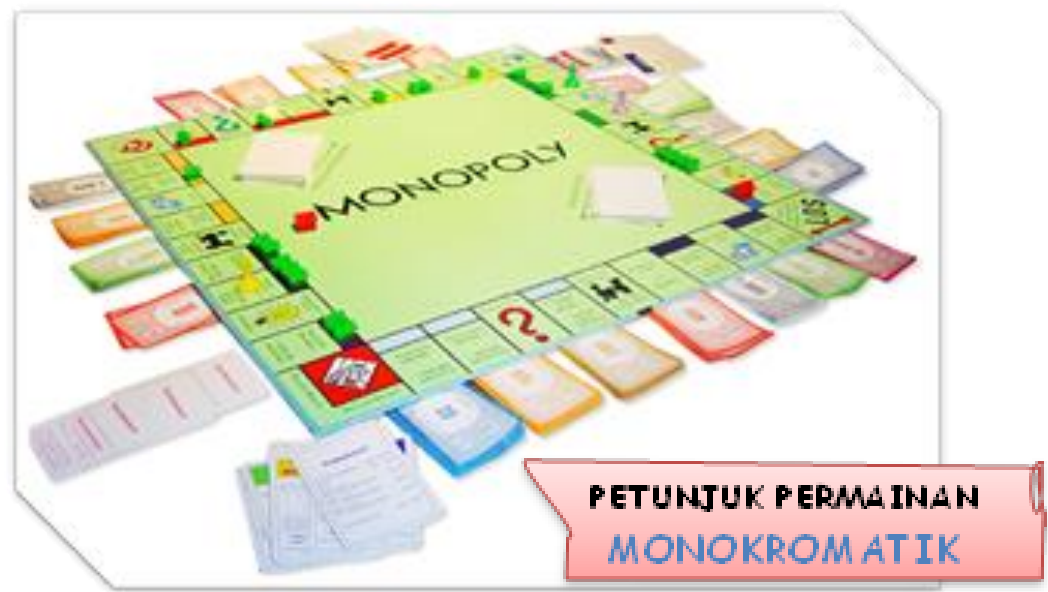

\section{Gambar 6 Petunjuk Permainan}

Simbol rumah pada permaianan monokromatik ini menggunakan kancing baju yang besar Dalam satu box permaianan monopoli akan mendapatkan 40 keping kancing berwarna kuning terang.

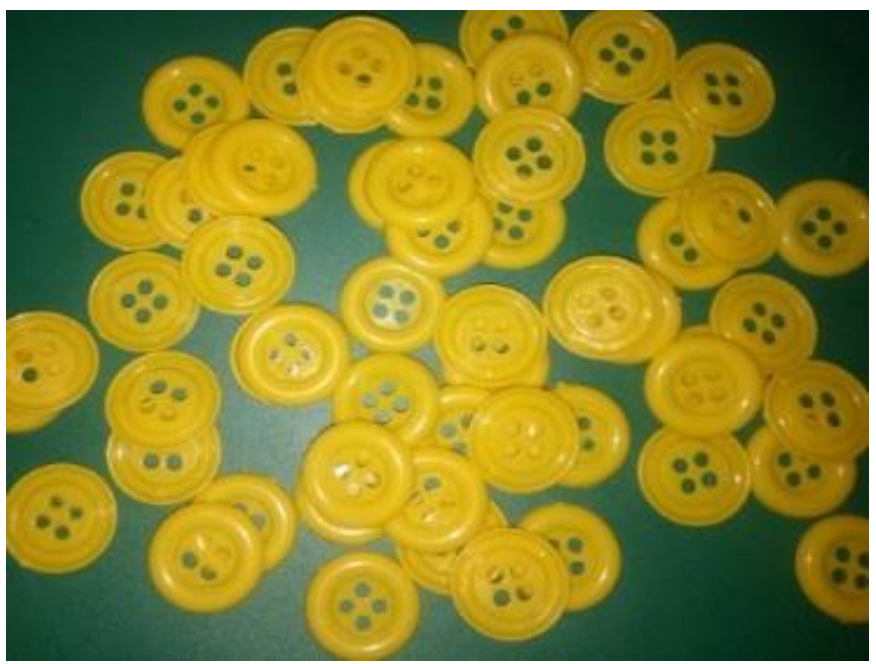

Gambar 4.7 Simbol Rumah

Simbol rumah pada monokromatik menggunakan kancing baju yang besar warna merah terang. Dalam satu box permaianan monopoli akan mendapatkan 10 keping kancing. 


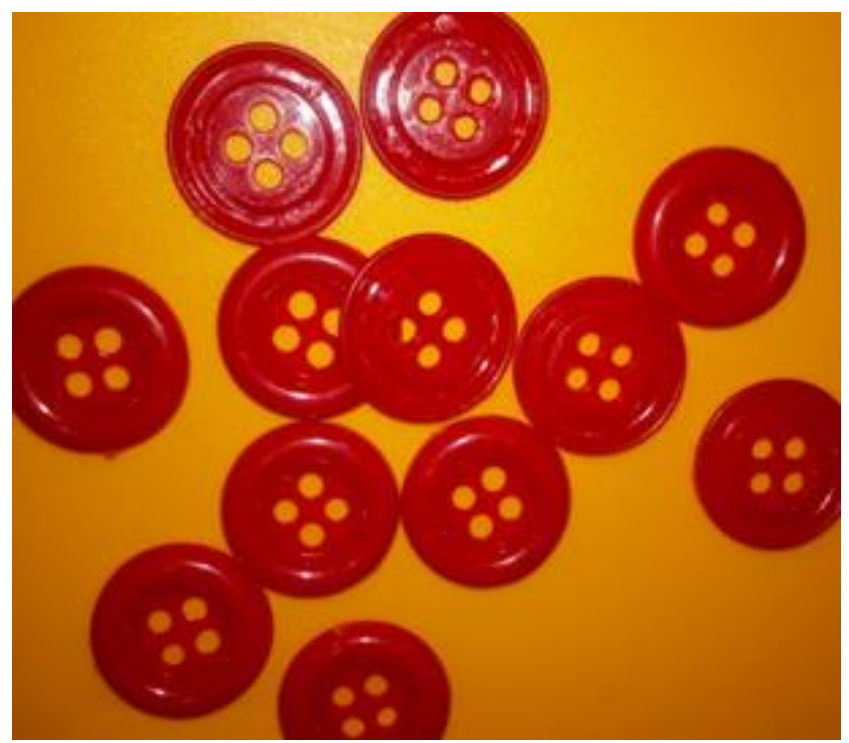

\section{Gambar 8. Simbol Hotel}

Dadu yang digunakan pada media monokromatik berbahan kain flannel yang berwarna biru muda dengan kombinasi kuning terang sebagai alas pembungkus, kemudian dakron bantal sebagai isi dadu. Untuk bagian titik-titik diluarnya menggunakan kain flannel hitam yang dipotong bulat kecil lalu ditempel dengan lem. Pada setiap box permainan dadu yang diberikan adalah 2 buah. Pion

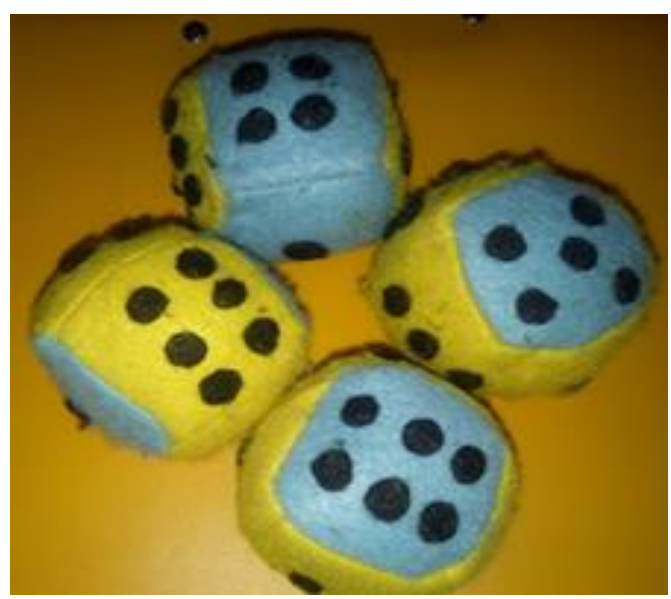

Gambar 9 Dadu

Dirasah, Vol. 2, No. 2, Agustus 2019 
Pion dalam permainan monokromatik ini adalah sebagai pemain yang melaju dipapan permainan. Pion ini terdiri dari bahan daur ulang yaitu tutup botol mineral bekas yang dibungkus menggunakan kain flannel dan berbeda warnaya

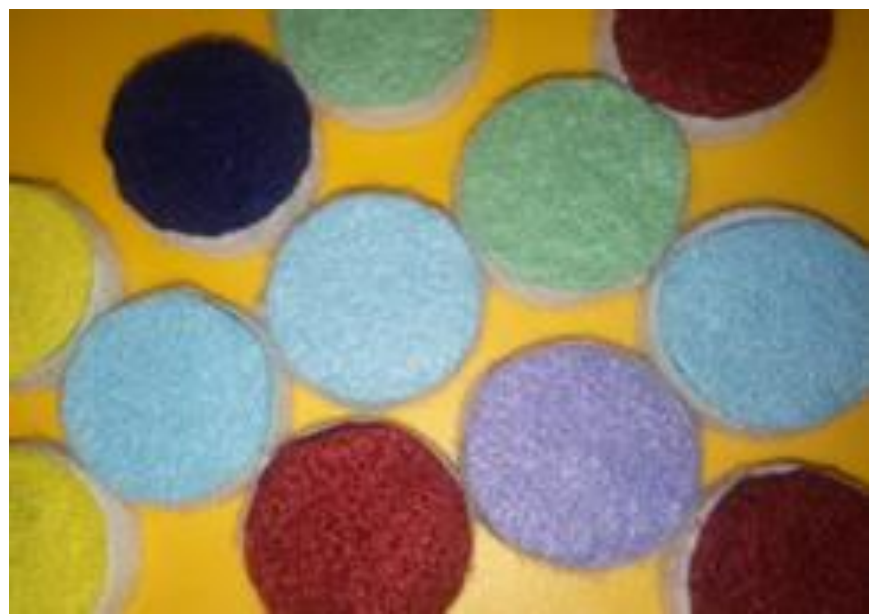

lalu ditempelkan menggunakan lem. Dalam satu box permainan ini terdiri dari 6 pion

\section{Gambar 10. Pion}

Kotak monokromatik ini difungsikan sebagai wadah agar komponenkomponen yang lain mudah dalam penyimpanannya. Bahan yang digunakan adalah dari kayu dan juga triplek yang kemudian disusun sesuai dengan bagiannya masing-masing. Setelah itu diberikan warna pada kayu agar lebih menarik. Untuk ukuran kotak monopoli ini adalah $100 \mathrm{cmx} 80 \mathrm{~cm}$.

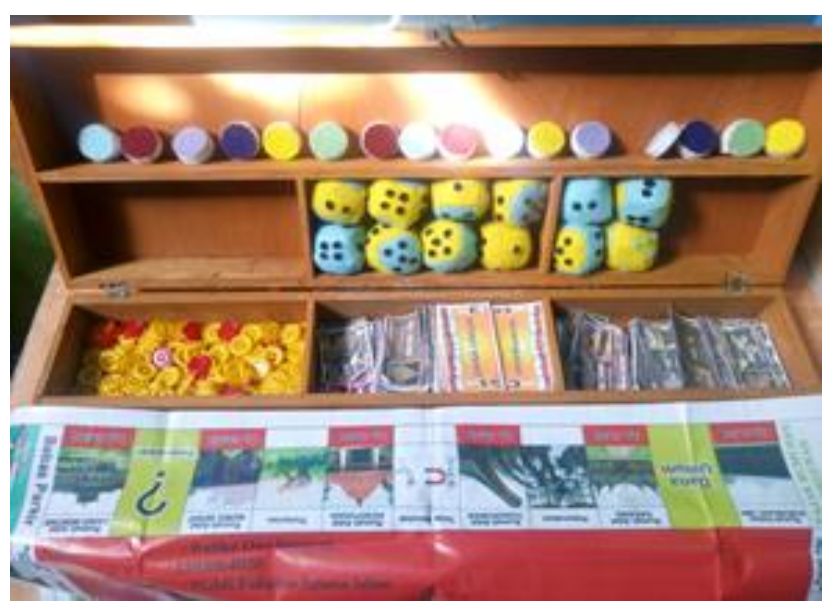

Gambar 11. Kotak Monopoli

Dirasah, Vol. 2, No. 2, Agustus 2019 
Setelah menyelesaikan rincian desain produk selanjutnya dilakukan validasi oleh validator ahli dibidangnya. Data hasil validasi yang diperoleh berupa data kualitatif berrdasarkan kritik, saran dan tanggapan dari validator serta data kuantitatif yang diperoleh dari hasil angket penilaian validator.

Validasi tahap 1 oleh ahli materi didapatkan nilai prosentase sebesar $86 \%$. Jika dicocokkan dengan tabel kriteria kelayakan maka skor tersebut termasuk sangat valid atau sangat layak, namun menurut ahli materi/isi terdapat beberapa bagian yang perlu diperbaiki lagi. Setelah dilakukan revisi pada tahap 2 mendapatkan prosentasi kevalidan yang dihasilkan adalah sebesar 92\%. jika dicocokkan dengan tabel kriteria kelayakan skor diatas suadh termasuk sangat valid atau sangat layak.

Selanjutnya dari validasi desain diperoleh hasil $84 \%$ dari keseluruhan penilaian oleh ahli desain. Jika dicocokkan dengan tabel kriteria kevalidan / kelayakan termasuk dalam kriteria sangat valid. Akan tetapi menurut ahli desain masih memerlukan perbaikan agar media lebih baik. Setelah dilakukan revisi pada tahap 2 persentasi kevalidan yang dihasilkan adalah sebesar 92\% . jika dicocokkan dengan tabel kriteria kelayakan skor diatas sudah termasuk sangat valid atau sangat layak.

Validasi oleh ahli pembelajaran secara keseluruhan mendapatkan skor 70\% dan termasuk valid. Namun berdasarkan saran dan masukan dari ahli materi beberapa bagian perlu diperbaiki agar mendapatkan hasil yang maksimal. Setelah malaksanakan revisi kemudian proses validasi tahap kedua, berdasarkan perhitungan diatas maka didapatkan prosentase sebesar $92 \%$ dan jika dicocokkan dengan tabel kriteria kelayakan hasil tersebut termasuk sangat valid atau sangat layak.

Setelah produk dinyatakan layak oleh validator ahli, tahap selanjutnya yaitu uji coba produk terhadap siswa. Uji coba dilakukan secara 2 kali yaitu kelompok kecil dan kelompok besar. Uji coba lapangan kelompok kecil dilaksanakan oleh siswa kelas IV sejumlah 8 responden dan diambil secara random dan diperoleh prrosentase yang didapatkan adalah sebesar 90,2\%, jika di lihat dari skala pencapaian termasuk Sangat valid atau tidak perlu adanya perbaikan. Sedangkan pada uji coba lapangan kelompok besar dilaksanakan pada siswa kelas IV MI Al Ittihad Jogoroto jombang dengan responden yang mengikuti uji coba sejumlah 
16 siswa dengan memperoleh prosentase sebesar 88,7\% dan apabila dicocokkan sesuai dengan kriteria tingkat ketertarikan media monopoli berbasis triprakoro sudah termasuk sangat menarik bagi siswa kelas IV MI AL-Ittihad Jogoroto.

\section{Penutup}

Proses pengembangan monokromatik memiliki beberapa tahapan sesuai dengan model pengembangan dari Borg and Gall yang diadaptasi menjadi delapan tahapan, Tahapan-tahapan tersebut diawali dengan penemuan potensi dan masalah yang didapatkan dari observasi ke sekolah. Kemudian dilanjutkan dengan penggalian data melalui wawancara terhadap guru dan juga siswa. Berdasarkan data-data yang diperoleh peneliti melakukan penyusunan konsep dan desain pengembangan monokromatik, melakukan validasi desain produk kepada bebrapa ahli dibidangnya yaitu ahli materi, ahli desain dan ahli pembbelajaran untuk mendapatkan saran dan masukan, memperbaiki desain berdasarkan saran dan masukan dari validator, uji coba produk dalam skala kecil dan besar untuk mengetahui efektifitas monokromatik.

Validasi media monopoli berbasis triprakoro (monokromatik) didasarkan pada hasil dari validator ahli materi/isi pembelajaran tematik mencapai presentase sebesar 92\% yang menyatakan bahwa media monokromatik sangat valid untuk digunakan. Validator ahli desain pembelajaran tematik mencapai presentase sebesar $92 \%$ yang artinya bahwa media monokromatik sangat valid. Validator ahli pembelajaran tematik juga mencapai presentase sebesar $92 \%$ yang menyatakan bahwa media monokromatik sangat valid untuk digunakan. Serta hasil uji coba lapangan terhadap siswa memperoleh presentase sebesar 88,7\% yang memiliki kualifikasi valid.

\section{Daftar Pustaka}

Kemendikbud. kemendikbud siapkan kesiapan guru hadapi tantangan abad ke 21. http:/www.kemendikbud.go.id diakses tanggal 25 november 2018

Lamatenggo Hamzah, Nina. 2011. Teknologi Komunikasi \& Informasi Pembelajaran Jakarta: PT. Bumi Aksara

Dirasah, Vol. 2, No. 2, Agustus 2019 
Mulyasa. 2015. Pengembangan dan Implementasi Kurikulum 2013, Bandung: PT Remaja Rosda Karya

Rusman. 2014. Model-Model Pembelajaran Mengembangkan Profesionalisme Guru. Jakarta:Raja Grafindo Persada

Sudijino, Anas. 2009. Pengantar Evaluasi Pendidikan. Jakarta: PT. Raja Grafindo

Sugiyono. 2016. Metode Penelitian Kuantitatif, Kualitatif, dan $R \& D$, Cet.24 Bandung: Alfabeta

Sugiyono. 2017. Metode Penelitian Pendidikan Pendekatan Kuantitatif, Kualitatif, dan $R \& D$. Cet. 25 Bandung: ALFABETA

Arikunto, Suharsimi. 2013. Prosedur Penelitian suatu Pendekatan Praktik. Jakarta: Rineka Cip

Susanto, Ahmad. 2016. Teori belajar dan Pembelajaran di Sekolah Dasar. Jakarta: Prenamedia Group

Undang-Undang dan Peraturan Pemerintahan RI tentang Pendidikan, 2006 Jakarta: Departemen Agama RI

Zetti finali, "Pegembangan RPP Pkn Berbasis Model Triprakoro Dan Budaya Lokal (Using) Untuk Mengembangkan Nilai Komunikatif Pada Kelas IV Sekolah Dasar”, Jurnal Pendidikan, vol.5 (Universitas Negeri Malang: 2016)

Copyright () 2019 Journal Dirasah: Vol. 2, No. 2, Agustus 2019, p-ISSN: 2615-0212, e-ISSN; 2621-2838

Copyright rests with the authors

Copyright of Jurnal Dirasah is the property of Jurnal Dirasah and its content may not be copied or emailed to multiple sites or posted to a listserv without the copyright holder's express written permission. However, users may print, download, or email articles for individual use.

https://ejournal.iaifa.ac.id/index.php/dirasah 